\title{
Developing countries plan to displace Blix at IAEA
}

\section{Vienna}

STORM clouds have appeared on the horizon at the International Atomic Energy Agency (IAEA). The agency had emerged as a poised leader in the international response to the 1986 Chernobyl nuclear accident and had pleased its sponsors in the developed world. But the time of tranquillity may soon come to an end.

The Group of 77 (G77), which represents developing countries in international agencies such as the United Nations (UN) and the IAEA, announced its dissatisfaction earlier this spring with the proposed agency budget for 1989 and with Hans Blix, the agency's director-general. G77 has hinted that it will announce its own candidate for director-general before Blix's second term ends in 1989.

The Vienna head of G77, Mexican Ambassador Francisco Cuevas Cancino, denounced a proposed increase in the IAEA's $\$ 50$ million annual budget for nuclear safeguards. The safeguards increase would require cuts in IAEA programmes in developing countries.

According to the news agency IPS, Cuevas Cancino declared that the agency budget lacks "audacity" and "multilaterality." The criticism reflects a continuing struggle within the IAEA between states that have nuclear technology and those that do not. A few developed countries contribute the lion's share to the agency

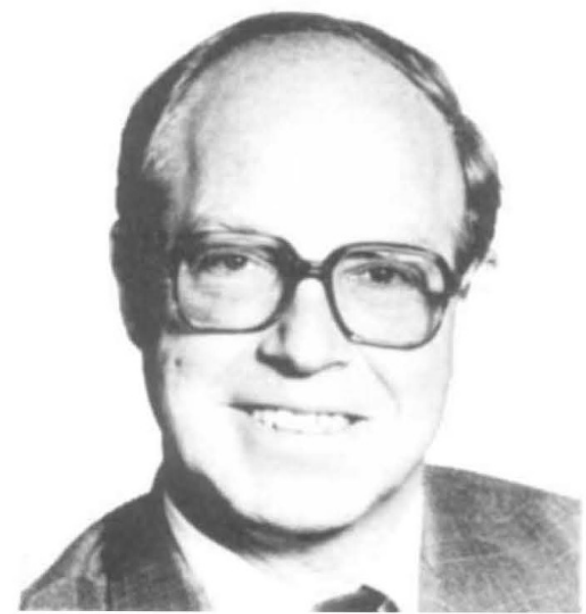

Hans Blix - director-general of the IAEA.

budget - G77 countries pay only 2 per cent of the safeguards budget, which is used to administer the 1971 non-proliferation treaty to prevent the diversion of nuclear material for use in weapons.

But many developing nations benefit from IAEA programmes in nuclear medicine and agriculture. Thus, in addition to serving as a nuclear inspection squad for the developed world, the IAEA is also a conduit for the transfer of technology to less developed countries.
A proposed increase of $\$ 2$ million in the safeguards budget for 1989 brought on the current disagreement. Some of the money derived from efficiency gains in nonsafeguards areas. The increase pushed the safeguards budget to slightly more than one-third of the IAEA's total budget.

Blix last week compared his budget task to "squaring the circle". The work load of the agency has been increasing, without a corresponding increase in the safeguards budget, which has stayed the same for the past four years. At the same time, developing countries demand that the balance between safeguards and other programmes should remain the same.

Blix tried to accomplish the impossible by asking developed countries to provide more money in the form of voluntary contributions. His request was rejected.

The latest form of Blix's budget, in which a few posts have been shifted out of the safeguards area, will be voted on at the June board of governors meeting in Vienna. Blix predicts that his compromise proposal will be accepted by the board.

Challenging Blix for the post of director general will not be as easy for G77 as challenging the budget. Despite a 1985 understanding that Blix would be replaced by a candidate from G77 in 1989, IAEA sources consider it unlikely that the G77 can unite behind a single person. There are some nuclear experts from developing countries who would be available and eager to take the job.

Blix will announce his decision to run before the IAEA general conference in September 1988. The election will take place at the general conference in September 1989.
Steven Dickman

\section{Where does India find heavy water for Candu reactors?}

\section{New Delhi}

A REPORT giving weight to international press reports alleging that India might have acquired heavy water illegally - outside the provisions of the Nuclear Nonproliferation Treaty - has just been released by the comptroller and auditor general (CAG) of India The report has shattered official claims about self-sufficiency in heavy water.

The audit report infers that India produced less than 200 tonnes of heavy water in the period $1978-86$, at a time when three Candu reactors were brought into service, requiring a total of 578 tonnes of heavy water. India claimed that the heavy water used in these reactors was its own.

The report has received wide publicity in the wake of a new allegation that 15 tonnes of heavy water found missing in a Norwegian plant in 1983 might have ended up in India. The government's denial has been weakened by the audit report, which suggests that the stock of indigenous heavy water fell far short of the quantity needed to charge the two reactors of the Madras Atomic Power Project (MAPP), and the Dhruva research reactor in Bombay. MAPP-I, commissioned in July 1983, and MAPP-II, commissioned in 1985, each required 250 tonnes; Dhruva needed 78 tonnes.

The report says that the Tuticorin heavy water plant, commissioned in July 1978, was the best among all operational plants, and yet its average annual production for eight years was only 20 per cent of its rated capacity of 71 tonnes. Between 1978 and 1986 , this plant produced a total of 114 tonnes - " 60 per cent of the indigenous heavy water".
An official of the CAG office says that it took a "circuitous" approach in stating the cumulative production in keeping with the policy of the Department of Atomic Energy (DAE) of secrecy over exact production figures of individual plants. The DAE declared such information as classified soon after commissioning MAPP-I, apparently to ward off speculation about the source of heavy water

The DAE has admitted that in July 1982 , its stock consisted of 45 tonnes of fresh heavy water and 105 tonnes of used heavy water that required upgrading. But it has not explained how it managed to make up the shortfall of 428 tonnes between 1983 and 1985 . Only three heavy water plants - at Nangal, Baroda and Tuticorin - were then operating and, if the CAG report is correct, they would have produced at best 80 tonnes.

US reports two years ago that India had made up its shortage of heavy water by importing it from China and by siphoning it off from the disused Rajasthan atomic station were denied by the Indian government. The Soviet Union has officially stated that it has so far supplied 450 tonnes of heavy water to India under the safeguards of the anti-proliferation treaty. This, according to DAE, has been used in the two reactors of the Rajasthan heavy atomic power station.

India has six operational heavy water plants, with a total capacity of 350 tonnes, and the seventh is under construction. The present stock is not known but DAE would need 250 tonnes for the first unit of the Narora atomic power project scheduled to become critical before the end of the year. 